\title{
Pruning Wound Protection Strategies for Simultaneous Control of Eutypa and Botryosphaeria Dieback in New Zealand
}

\author{
Mark R. Sosnowski ${ }^{1,2, \dagger}$ and Dion C. Mundy ${ }^{3}$ \\ ${ }^{1}$ South Australian Research and Development Institute, Adelaide, SA, 5001, Australia; ${ }^{2}$ School of Agriculture, Food and Wine, \\ Waite Research Institute, The University of Adelaide, Adelaide, SA 5005, Australia; and ${ }^{3}$ The New Zealand Institute for Plant \& \\ Food Research Limited, Marlborough Wine Research Centre, Blenheim 7240, New Zealand
}

\begin{abstract}
The grapevine trunk diseases Eutypa and Botryosphaeria dieback threaten the sustainability of vineyards worldwide. This study aimed to develop practical and efficient wound protection strategies, which will lead to widespread adoption of preventative control for these diseases and increased longevity of vineyards. Five fungicides (tebuconazole, carbendazim, fluazinam, mancozeb, and flusilazole) were evaluated for efficacy against Eutypa lata and Neofusicoccum luteum infection on pruning wounds of 'Sauvignon blanc' in a New Zealand vineyard. All five fungicides

controlled infection by both pathogens to varying degrees, with mean percent disease control of 70 to $90 \%$ for E. lata and 33 to $93 \%$ for $N$. luteum This has led to the first known registration of a fungicide, fluazinam (Gem), for simultaneous control of both Eutypa and Botryosphaeria dieback. Furthermore, application of carbendazim with tractor-driven sprayers provided similar control of $E$. lata and $N$. luteum to that when applied by hand with a paintbrush. This constitutes the first report of Botryosphaeria dieback control with fungicides applied with tractor-driven sprayers.
\end{abstract}

Eutypa and Botryosphaeria dieback are major grapevine trunk diseases (GTDs) worldwide, causing significant reduction in grape yield and quality (Gramaje et al. 2018). Grape yield losses of 1,500 kg/ha have been reported from Eutypa dieback in Australian 'Shiraz' vineyards (Wicks and Davies 1999). The cost of GTDs to the Californian industry was estimated at US\$260 million per annum (Siebert 2001). More recently, in the Napa Valley of California, Sipiora and Cuellar (2014) reported annual losses of US $\$ 16,000$ per acre from Eutypa dieback in 'Cabernet Sauvignon' from reduced grape production and shortened vineyard lifespan. It has been demonstrated in California and New Zealand that early adoption of management strategies, including protection of pruning wounds, can offset the negative effects of GTDs (Kaplan et al. 2014; Sosnowski and McCarthy 2017).

Trunk pathogens infect vines through pruning wounds, in the case of Eutypa dieback by wind and splash-dispersed ascospores of Eutypa lata and other Diatrypaceous spp. (Carter 1991; Trouillas et al. 2010, 2011), and in the case of Botryosphaeria dieback by splash-dispersed conidia of Botryosphaeriaceous spp. (Úrbez Torres 2011). With both diseases, spores germinate in xylem vessels and colonize woody tissue to cause dieback of cordons and trunks, typically observed as external cankers and dark-stained, dead tissue in cross section. E. lata produces toxic metabolites, which are translocated to the foliage, causing stunted shoots, necrotic and distorted leaves, reduced bunch size, and uneven ripening (Moller and Kasimatis 1981; Molyneux et al. 2002; Tey-Rulh et al. 1991).

Based on previous studies, both in vitro and in planta, the most effective fungicides reported against species that cause Eutypa and Botryosphaeria dieback were carbendazim, fluazinam, flusilazole, mancozeb, myclobutanil, pyraclostrobin, pyrimethanil, tebuconazole, and thiophanate-methyl (Gramaje et al. 2018). Prior to the current study, a limited number of products were registered for Eutypa dieback control in New Zealand: a biocontrol Vinevax (Trichoderma

${ }^{\dagger}$ Corresponding author: Mark R. Sosnowski;

E-mail: mark.sosnowski@sa.gov.au

Funding: This study was supported with funding from New Zealand Winegrowers and the New Zealand Ministry for Primary Industries Sustainable Farming Fund.

Accepted for publication 9 September 2018.

C 2019 The American Phytopathological Society spp.; Agrimm Technologies, Lincoln, New Zealand) and several sealant products-Greenseal Ultra (containing tebuconazole and octhilinone; PGG Wrightson Limited, Christchurch, New Zealand), Gelseal (tebuconazole and boric acid; Omnia Specialties NZ Ltd., Auckland, New Zealand), Bacseal Super (tebuconazole; Bayer New Zealand Limited, Auckland, New Zealand), and Garrison Rapid (cyproconazole and iodocarb; Chemcolour Industries NZ Ltd., Auckland, New Zealand)—with only PruneTec (tebuconazole; Max Stanton Moore, Christchurch, New Zealand) also registered for control of Botryosphaeria dieback. These treatments can only be applied by hand, which is labor-intensive and expensive. The efficacy of applying pruning wound treatments with tractor-driven sprayers has been demonstrated for Eutypa dieback (Ayres et al. 2017; Herche and Gubler 2010; Lecomte et al. 2003; Ramsdell 1995; Sosnowski et al. 2013) but has yet to be evaluated for Botryosphaeria dieback.

Therefore, the aims of this study were to compare the efficacy of liquid formulation fungicide treatments for simultaneous control of Eutypa and Botryosphaeria dieback in New Zealand and to evaluate the efficacy of applying wound protectant with tractor-driven sprayers on both cordon and cane-pruned grapevines.

\section{Materials and Methods}

Fungicide selection. Fungicides and application rates were chosen based on previous studies and the currently registered label rates of fungicides in New Zealand for other diseases of grapevines or different hosts (Table 1). Products were selected in consultation with agrochemical companies that were committed to the potential registration of products for control of Eutypa and Botryosphaeria dieback.

Inoculum preparation. For Eutypa dieback, E. lata ascospores were obtained from fruiting bodies, using methods similar to those described by Carter (1991). This involved attaching pieces of dead grapevine wood containing perithecia to a plastic lid and soaking them in a container of tap water for $1 \mathrm{~h}$. The lid, with wood attached, was then placed onto a clean plastic container and left overnight. The following day, spores were washed with tap water from the sides of the container into a suspension and adjusted to 25,000 spores $/ \mathrm{ml}$ based on counts from a hemocytometer.

For Botryosphaeria dieback, Neofusicoccum luteum (MM 562) was grown on potato dextrose agar (PDA; Oxoid, Basingstoke, U. K.) in Petri dishes and incubated under warm white fluorescent and near ultraviolet light for a 12-h photoperiod at approximately $20^{\circ} \mathrm{C}$ for 3 weeks. Spores (conidia) that developed in pycnidia that 
formed on the agar were washed with sterile distilled water from the plates and the concentration adjusted to 25,000 spores $/ \mathrm{ml}$ based on counts from a hemocytometer.

Spore germination was assessed for both pathogens by placing five drops of the spore suspension on a PDA plate, which was then incubated in the laboratory under cool daylight fluorescent light for a 12 -h photoperiod at approximately $20^{\circ} \mathrm{C}$. After approximately $8 \mathrm{~h}$ ( $N$. luteum) or $24 \mathrm{~h}$ (E. lata), a glass cover slip was placed over the spores on the PDA, and using a compound microscope (Leitz, Leica Microsystems, Wetzlar, Germany) at 200× magnification, the number of nongerminated spores/100 in each of the drops was counted, and a mean percentage of germinated spores was determined.

Immediately prior to inoculation, a drop of Tween $80(\mathrm{BDH}$, Poole, U.K.) was added to the suspensions as a surfactant to assist spread of spores over the wound surface.

Detached cane assays (DCAs). DCAs were established at the Marlborough Research Centre in New Zealand, based on methods used by Ayres et al. (2017), to evaluate pruning wound treatments for the control of Eutypa and Botryosphaeria dieback.

Sauvignon blanc grapevine canes were collected during dormancy and stored in plastic bags at 3 to $4^{\circ} \mathrm{C}$ before being cut into $10-\mathrm{cm}$ single-node sections using secateurs, with the top cut being $1 \mathrm{~cm}$ above the node. Canes were placed into holes in 12-mm-thick polystyrene boards, ensuring that the bottom of the canes extended at least $1 \mathrm{~cm}$ below the boards. The boards with canes were floated on tap water in plastic tubs.

DCA 1 was established in a vented greenhouse without temperature control on 6 November 2013 to evaluate five fungicide pruning wound treatments (Table 1) against E. lata. On the day that canes had been cut and placed into boards, treatments were applied to the top wound surface of canes with a paintbrush until runoff. Controls were treated with water and were either inoculated (IC) or noninoculated (NIC). The following day, all wound surfaces were premoistened by spraying with sterile distilled water (SDW) before inoculating (except NICs) with a $20-\mu 1$ droplet of SDW containing approximately 500 ascospores of $E$. lata. The experiment was arranged as a randomized block design with 10 canes per treatment plot and five replications. The experiment was repeated on 23 January 2014 (DCA 2), except that canes were maintained at $20^{\circ} \mathrm{C}$ on laboratory benches with 8-h cool daylight fluorescent light and 16-h dark cycle for the duration of the experiment.

DCA 3 was established on 26 March 2015 to evaluate five pruning wound treatments (Table 1) against $N$. luteum. The experiment was established as in DCA 2, with wounds inoculated with 500 conidia of $N$. luteum. The experiment was repeated on 13 January 2016 (DCA 4).
For all experiments, canes were removed from polystyrene boards after 6 to 8 weeks and air dried before storage in plastic bags at 3 to $4^{\circ} \mathrm{C}$ in the dark prior to assessment in the laboratory.

Vineyard fungicide evaluations. A vineyard trial was established on cane-pruned Sauvignon blanc vines planted on 'SO4' rootstock in 2001 in Marlborough, New Zealand, to evaluate the efficacy of five fungicides (Table 1) as pruning wound protectants against $E$. lata and N. luteum.

On 31 July 2013, vines were cane-pruned using loppers and secateurs, with four canes laid down on the trellis wire as well as a twobud spur left on the head of each vine and treated with tebuconazole $(0.129,0.258$, and $0.645 \mathrm{~g}$ active ingredient [a.i.]/liter of distilled water), carbendazim $(0.25,0.5$, and $1.25 \mathrm{~g}$ of a.i./liter), fluazinam $(0.5$, 1.0 , and $2.5 \mathrm{~g}$ of a.i./liter), mancozeb $(1.575,3.15$, and $7.875 \mathrm{~g}$ of a.i./liter), and flusilazole $(0.04,0.08$, and $0.2 \mathrm{~g}$ of a.i./liter) or distilled water as a control (IC). Concentrations were selected to represent one, two, and five times the recommended rate for foliar diseases of grapes and other crops in New Zealand (Table 1). Treatments were applied liberally, until runoff, using a paintbrush, to five pruning wounds on each of two vines per treatment within $2 \mathrm{~h}$ of pruning.

On 1 and 2 August 2013, wounds were sprayed with distilled water and then each wound inoculated twice, following the method of Ayres et al. (2017), with a 20- $\mu$ l droplet of SDW containing 250 E. lata ascospores or $500 \mathrm{~N}$. luteum conidia, which were prepared as described above. Each treatment and species combination was applied to 10 wounds across a two-vine plot, and the trial was designed as a randomized block with five replications. NICs were included to determine the incidence of natural infection. The trial was repeated in 2014 with pruning and treatments applied on 18 August and inoculations on 19 and 21 August.

For each trial, treated canes were removed from vines 1 year later, in July 2014 and 2015, respectively, and taken to the laboratory for storage in plastic bags at 3 to $4^{\circ} \mathrm{C}$ in the dark prior to assessment in the laboratory.

Spray application vineyard evaluation. A vineyard trial was established in Hawke's Bay, New Zealand, on cordon spur-pruned Cabernet Sauvignon vines, planted in 2000 on 'Couderc 3309' rootstock. One-year-old canes were pruned to two-bud spurs using secateurs on 23 August 2013. Three double-row tractor-driven sprayers were used: air-shear sprayer (Silvan, Hamilton, New Zealand) at water spray volumes (WSVs) of 300 and 600 liters/ha, modified weed sprayer (home-engineered; two nozzles positioned on a metal frame either side of the cordon) at WSVs of 100 and 200 liters/ha, and recycle sprayer (Spray-Pro R Series; FMR Group, Blenheim, New Zealand) at WSV of 900 liters/ha. Each sprayer was individually adjusted to maximize coverage by redirecting nozzles to focus on

Table 1. Fungicides, active ingredients, and manufacturers of products evaluated to control Eutypa lata and Neofusicoccum luteum in detached grapevine cane assays and field trials

\begin{tabular}{|c|c|c|c|c|}
\hline Trade name & $\begin{array}{l}\text { Active ingredient } \\
\text { (formulation) }\end{array}$ & $\begin{array}{l}\text { Application rate } \\
\text { (g of } \\
\text { a.i./liter) }\end{array}$ & Supplier & References $^{\mathbf{a}}$ \\
\hline Chief & Carbendazim (500 g/liter) & $0.5^{\mathrm{b}}$ & $\begin{array}{l}\text { Adama New Zealand Ltd., } \\
\text { Nelson, New Zealand }\end{array}$ & $\begin{array}{l}\text { Amponsah et al. (2012); Bourbos and Barbopoulou (2005); } \\
\text { Gramaje et al. (2012); Sosnowski et al. }(2008,2013)\end{array}$ \\
\hline Gem & Fluazinam $(500 \mathrm{~g} /$ liter $)$ & $0.5^{\mathrm{b}}$ & Adama New Zealand Ltd. & $\begin{array}{l}\text { Ayres et al. (2017); Bourbos and Barbopoulou (2005); } \\
\text { Gramaje et al. (2012); Savocchia et al. (2005); Sosnowski } \\
\text { et al. (2008, 2013) }\end{array}$ \\
\hline Megastar & Flusilazole $(200 \mathrm{~g} / \mathrm{kg})$ & $0.04^{\mathrm{c}}$ & $\begin{array}{l}\text { Grochem (AgriNova NZ } \\
\text { Ltd.), Porirua, New Zealand }\end{array}$ & $\begin{array}{l}\text { Amponsah et al. (2012); Bester et al. (2007); Halleen et al. } \\
\text { (2010); Munkvold and Marois (1993); Savocchia et al. } \\
\text { (2005); Sosnowski et al. (2008) }\end{array}$ \\
\hline Dithane & Mancozeb (750 g/kg) & $1.575^{\mathrm{b}}$ & $\begin{array}{l}\text { Dow Agrosciences (NZ) Ltd., } \\
\text { New Plymouth, New } \\
\text { Zealand }\end{array}$ & Amponsah et al. (2012) \\
\hline Folicur & Tebuconazole (430 g/liter) & $0.129^{c}$ & $\begin{array}{l}\text { Bayer New Zealand Ltd., } \\
\text { Auckland, New Zealand }\end{array}$ & $\begin{array}{l}\text { Amponsah et al. (2012); Ayres et al. (2017); Díaz and Latorre } \\
\text { (2013); Gramaje et al. (2012); Halleen et al. (2010); Pitt } \\
\text { et al. (2012); Savocchia et al. (2005); Sosnowski et al. } \\
\text { (2013) }\end{array}$ \\
\hline
\end{tabular}

\footnotetext{
a Previous reports of fungicide efficacy against species of the Diatrypaceae and Botryosphaeriaceae.

${ }^{\mathrm{b}}$ Application rate recommended for foliar diseases in grapevines in New Zealand.

${ }^{\mathrm{c}}$ Application rate recommended for foliar diseases in other crops in New Zealand.
} 
the pruning wound zone and turning off unnecessary nozzles. Each sprayer applied carbendazim at $0.5 \mathrm{~g}$ of a.i./liter of bore water.

Using methods described by Ayres et al. (2017), 10 pruning wounds per vine were covered with plastic bags $(10 \times 15 \mathrm{~cm})$ secured with rubber bands, except for the wounds for the treatment that were about to be sprayed. Following a given spray treatment, the treated canes were covered with plastic bags within $10 \mathrm{~min}$, and the next set of canes exposed for the succeeding spray treatment. This was repeated until all pruning wounds had received the appropriate spray treatment. A treatment of carbendazim ( $0.5 \mathrm{~g}$ of a.i./liter) was also applied liberally with a paintbrush until runoff for comparison along with a control (IC) treated with distilled water.

All wounds were inoculated twice, on 24 and 26 August 2013, with either $250 \mathrm{E}$. lata ascospores or $500 \mathrm{~N}$. luteum conidia. Each treatment and species combination was applied to 10 wounds on a vine and the trial was designed as a randomized block with five replications. NICs were included to determine the incidence of natural infection. Treated canes were removed on 11 June 2014 and stored in plastic bags at 3 to $4^{\circ} \mathrm{C}$ in the dark prior to assessment in the laboratory.

The trial was repeated in 2014 at the same vineyard but on nearby Cabernet Sauvignon vines planted in 2000 on 'Riparia Gloire' rootstock, pruned with secateurs, spray treatments applied, and the two inoculations undertaken on 6 and 8 August. Treated canes were removed on 7 May 2015 and were stored as described for 2014.

A second vineyard trial was conducted on Sauvignon blanc vines, planted on SO4 rootstock in 2001 in Marlborough, New Zealand. On 31 July 2013, vines were cane-pruned using loppers and secateurs, with four canes laid down on the trellis wire as well as a two-bud spur left on the head of each vine. Three sprayers were used: tangential sprayer (Bertolini Australasia, Hamilton, New Zealand) at WSVs of 300 and 600 liters/ha, air-shear sprayer (Silvan) at WSVs of 300 and 600 liters/ha, and recycle sprayer (Spray-Pro R Series) at WSV of 850 liters/ha.

As described above, sprayers were adjusted to focus on the pruning wound zone, each sprayer applied carbendazim at $0.5 \mathrm{~g}$ of a.i./liter in bore water, and pruning wounds were covered with plastic bags and uncovered as appropriate. A treatment of carbendazim $(0.5 \mathrm{~g}$ of a.i./liter) was also applied liberally with a paintbrush until runoff for comparison along with a control (IC) treated with distilled water.

All wounds were inoculated twice, on 31 July and 2 August 2013, with either 250 E. lata ascospores or $500 \mathrm{~N}$. luteum conidia. Each treatment and species combination was applied to 10 wounds across a two-vine plot, and the trial was designed as a randomized block with five replications. NICs were included to determine the incidence of natural infection. Treated canes were removed in July 2014 and stored in plastic bags at 3 to $4^{\circ} \mathrm{C}$ in the dark prior to assessment in the laboratory.

The trial was repeated in 2014, with pruning and spray treatments applied on 18 August and inoculations on 19 and 21 August. Treated canes were removed in June 2015 and were stored in a 3 to $4^{\circ} \mathrm{C} \mathrm{cool}$ room prior to assessment in the laboratory.
Spray coverage. For each trial, spray coverage was estimated using water-sensitive papers (WSPs; Syngenta Crop Protection, Auckland, New Zealand), which respond to contact with water by changing from yellow to blue. They were placed in four fixed positions on posts (front, back, left, and right) and six random positions throughout the pruning wound zone of vines. For each spray treatment, a fresh set of 10 papers was placed into position and then collected once the sprayer had passed and the paper dried. The percentage of each WSP that turned blue for each paper was quantified using ImageJ (Mangado et al. 2013). The relative spray coverage, as a mean of the 10 WSPs, was calculated for each of the spray treatments.

Assessment of infection. For all DCA and vineyard experiments, laboratory assessments were based on methods described by Sosnowski et al. (2013). Bark was removed, and the canes were surface disinfected for $10 \mathrm{~min}$ in $2.5 \%$ sodium hypochlorite (Janola, Shepparton, Australia) before rinsing twice in SDW. Each cane was cut into segments $(3 \times 2 \times 2 \mathrm{~mm})$ taken from the margin between live and dead wood tissue, and five segments were placed on each of two plates of PDA amended with streptomycin sulfate $(25 \mu \mathrm{g} / \mathrm{liter}$; Sigma-Aldrich, St. Louis, MO, U.S.A.). Samples of cane segments were incubated in the laboratory under cool daylight fluorescent light for a 12-h photoperiod for 7 days and then assessed for presence or absence of E. lata or N. luteum mycelial growth (Amponsah et al. 2011; Carter 1991).

Data for each trial were analyzed using a binomial generalized linear model with a logit link (Genstat 19th Ed; VSN International Ltd., Hemel Hempstead, U.K.). A Wald test was used to determine significant difference between treatments, and Fisher's least significant difference (LSD) test was used to compare treatments with ICs. Efficacy was presented as the mean percentage recovery (MPR) of E. lata or $N$. luteum from the treated canes by isolation on PDA. Data are also presented as mean percentage disease control (MPDC), which was calculated as the reduction in MPR as a proportion of the IC (Sosnowski et al. 2013).

\section{Results}

DCAs. In DCA 1 and 2, at the time of inoculation E. lata spore germination on PDA was 80 and $96 \%$, respectively, and E. lata was recovered from 46 and $77 \%$ of IC wounds, respectively (Table 2). E. lata was recovered from $4 \%$ of NIC wounds in DCA 2 , but none was recovered in DCA 1 . Owing to the large relative differences in recovery from treatments between DCAs, data were not pooled. In DCA 1 , there was a significant treatment effect $(P=$ 0.007 ) with all fungicides reducing MPR of E. lata to 2 to $12 \%$ compared with that of IC wounds (translating to MPDC of 74 to $96 \%$ when calculated as a proportion of the ICs). In DCA 2, there was a significant treatment effect $(P<0.001)$ with all fungicides, except for flusilazole, reducing MPR of E. lata to 8 to $50 \%$ (MPDC of 34 to $89 \%$ ).

In DCA 3 and 4, at the time of inoculation $N$. luteum spore germination on PDA was 80 and $98 \%$, respectively, and $N$. luteum was

Table 2. Efficacy of fungicides applied by hand using a paintbrush at various concentrations in detached grapevine cane assay (DCA) experiments following inoculation with 500 Eutypa lata ascospores or 500 Neofusicoccum luteum conidia, applied in $20-\mu 1$ droplets to each wound ${ }^{\text {a }}$

\begin{tabular}{|c|c|c|c|c|c|c|c|}
\hline \multirow[b]{4}{*}{ Fungicide } & \multirow[b]{4}{*}{ Concentration ( $\mathrm{g}$ of a.i./liter) } & \multirow{2}{*}{\multicolumn{4}{|c|}{ E. lata }} & \multirow{3}{*}{\multicolumn{2}{|c|}{$\begin{array}{c}\text { N. luteum } \\
\begin{array}{c}\text { Combined } \\
\text { experiments }\end{array}\end{array}$}} \\
\hline & & & & & & & \\
\hline & & \multicolumn{2}{|c|}{ DCA 1} & \multicolumn{2}{|c|}{ DCA 2} & & \\
\hline & & $\mathbf{M P R}^{\mathbf{b}}$ & MPDCc $^{c}$ & MPR & MPDC & MPR & MPDC \\
\hline Inoculated control & $\ldots$ & 46 & $\ldots$ & 77 & $\ldots$ & 32 & $\ldots$ \\
\hline Carbendazim & 0.5 & $8^{*}$ & 83 & $8^{*}$ & 89 & 16 & 48 \\
\hline Fluazinam & 0.5 & $2 *$ & 96 & $31 *$ & 58 & $8^{*}$ & 75 \\
\hline Flusilazole & 0.04 & $12^{*}$ & 74 & 66 & 13 & $11^{*}$ & 66 \\
\hline Mancozeb & 1.575 & $8^{*}$ & 83 & $42 *$ & 45 & $13^{*}$ & 61 \\
\hline Tebuconazole & 0.129 & $12^{*}$ & 74 & $50^{*}$ & 34 & $1 *$ & 96 \\
\hline
\end{tabular}

a Values with an asterisk are significantly different from the inoculated control according to Fisher's LSD test.

${ }^{\mathrm{b}}$ Efficacy was based on the mean percent recovery (MPR) of E. lata or $N$. luteum from the treated canes by isolation on potato dextrose agar.

${ }^{\mathrm{c}}$ Mean percent disease control (MPDC) of treatments was calculated as the reduction in MPR as a proportion of the inoculated control. 
recovered from 20 and $48 \%$ of IC wounds, respectively (Table 2). $N$. luteum was recovered from $6 \%$ of NIC wounds in DCA 4 , but none was recovered in DCA 3. Relative recovery from treatments was similar between DCAs, so data were pooled. There was a significant treatment effect $(P=0.007)$ with all fungicides, except for carbendazim, reducing MPR of $E$. lata to 1 to $16 \%$ (MPDC of 61 to $96 \%$ ).

Vineyard fungicide evaluations. For E. lata, spore germination on PDA for both inoculation times was 91 to $93 \%$ in 2013-14 and 91 to $95 \%$ in 2014-15, and E. lata was recovered from 56 and $55 \%$ of IC wounds, and from 3 and $6 \%$ of NIC wounds, respectively. Relative recovery from treatments was similar between trials, so data were pooled. There was a significant treatment effect $(P<0.001)$ with all fungicide treatments reducing MPR of E. lata to 6 to $17 \%$ compared with $56 \%$ from the IC wounds (MPDC of 70 to $90 \%$; Table 2).

For N. luteum, spore germination on PDA for both inoculation times was $96 \%$ in 2013-14 and 90 to $97 \%$ in 2014-15. The MPRs from IC wounds were 89 and $60 \%$ in $2013-14$ and 2014-15 (Table 3 ) and were 17 and $12 \%$ from NIC wounds, respectively. Owing to the large relative differences in recovery from treatments between trials, data were not pooled. In 2013-14, there was a significant treatment effect $(P<0.001)$ with all fungicide treatments, except for the lowest concentrations of mancozeb and flusilazole and the second lowest concentration of fluazinam, reducing MPR of $N$. luteum to 22 to $60 \%$ (MPDC 33 to 76\%). In 2014-15, there was a significant treatment effect $(P=0.002)$ with all fungicide treatments reducing MPR of $N$. luteum to 4 to 27\% (MPDC 55 to 93\%).

Spray application vineyard evaluation. In Hawke's Bay, E. lata spore germination on PDA for both inoculation times was 74 to $87 \%$ in 2013-14 and 82 to $93 \%$ in 2014-15. The MPRs from IC wounds were 30 and $42 \%$ in 2013-14 and 2014-15, respectively. E. lata was recovered from 5\% of NIC wounds in 2013-14, but none was recovered in 2014-15. Relative recovery from treatments was similar between trials, so data were pooled. There was a significant treatment effect $(P=0.002)$ with all applications of carbendazim reducing the MPR of E. lata to between 7 and $14 \%$ compared with MPR of $39 \%$ in the IC wounds (MPDC of 63 to $81 \%$; Table 4).

$N$. luteum spore germination on PDA for both inoculation times was 75 to $100 \%$ in $2013-14$ and 84 to $86 \%$ in $2014-15$. MPR of $N$. luteum from IC wounds was 90 and $48 \%$ in 2013-14 and 2014-15 (Table 4) and was 72 and 25\% from the NIC wounds, respectively. Owing to the large relative differences in recovery from

Table 3. Efficacy of fungicides applied by hand using a paintbrush to freshly cut wounds at different concentrations in a Marlborough 'Sauvignon blanc' vineyard in 2013-14 and 2014-15, followed by two inoculations of 250 Eutypa lata ascospores or 500 Neofusicoccum luteum conidia, applied in 20- $\mu$ d droplets to each wound ${ }^{\mathrm{a}}$

\begin{tabular}{|c|c|c|c|c|c|c|c|}
\hline \multirow[b]{3}{*}{ Fungicide } & \multirow[b]{3}{*}{ Concentration (g of a.i./liter) } & \multirow{2}{*}{\multicolumn{2}{|c|}{$\begin{array}{c}\text { E. lata } \\
\text { Combined years }\end{array}$}} & \multicolumn{4}{|c|}{ N. luteum } \\
\hline & & & & \multicolumn{2}{|c|}{ 2013-14 } & \multicolumn{2}{|c|}{ 2014-15 } \\
\hline & & $\mathbf{M P R}^{\mathbf{b}}$ & MPDC $^{c}$ & MPR & MPDC & MPR & MPDC \\
\hline Inoculated control & $\ldots$ & 56 & $\ldots$ & 89 & $\ldots$ & 60 & $\ldots$ \\
\hline \multirow[t]{3}{*}{ Carbendazim } & 0.25 & $9 *$ & 85 & $59 *$ & 34 & $17 *$ & 71 \\
\hline & 0.5 & $17^{*}$ & 70 & $53 *$ & 40 & $10^{*}$ & 83 \\
\hline & 1.25 & $7 *$ & 86 & $55^{*}$ & 39 & $8^{*}$ & 87 \\
\hline \multirow[t]{3}{*}{ Fluazinam } & 0.5 & $10 *$ & 82 & $57 *$ & 35 & $8^{*}$ & 86 \\
\hline & 1.0 & $11^{*}$ & 80 & 69 & 23 & $17^{*}$ & 72 \\
\hline & 2.5 & $11^{*}$ & 80 & $40^{*}$ & 55 & $8^{*}$ & 86 \\
\hline \multirow[t]{3}{*}{ Flusilazole } & 0.04 & $9 *$ & 84 & 77 & 13 & $18^{*}$ & 69 \\
\hline & 0.08 & $11^{*}$ & 80 & $54 *$ & 39 & $16^{*}$ & 73 \\
\hline & 0.2 & $7 *$ & 88 & $43 *$ & 51 & $6^{*}$ & 91 \\
\hline \multirow[t]{3}{*}{ Mancozeb } & 1.575 & $7 *$ & 88 & 74 & 18 & $27 *$ & 55 \\
\hline & 3.15 & $8^{*}$ & 85 & $60 *$ & 33 & $14^{*}$ & 77 \\
\hline & 7.875 & $6^{*}$ & 90 & $57 *$ & 36 & $17^{*}$ & 71 \\
\hline \multirow[t]{3}{*}{ Tebuconazole } & 0.129 & $9 *$ & 84 & $33 *$ & 63 & $4 *$ & 93 \\
\hline & 0.258 & $7 *$ & 88 & $22 *$ & 76 & $12^{*}$ & 80 \\
\hline & 0.645 & $7 *$ & 87 & $33 *$ & 63 & $10^{*}$ & 83 \\
\hline
\end{tabular}

a Values with an asterisk are significantly different from the inoculated control according to Fisher's LSD test.

${ }^{\mathrm{b}}$ Efficacy was based on the mean percent recovery (MPR) of $E$. lata or $N$. luteum from the treated canes by isolation on potato dextrose agar.

${ }^{\mathrm{c}}$ Mean percent disease control (MPDC) of treatments was calculated as the reduction in MPR as a proportion of the inoculated control.

Table 4. Efficacy of carbendazim when applied to fresh grapevine pruning wounds at $0.129 \mathrm{~g}$ of a.i./liter using tractor-driven sprayers with variable water output rates in Hawke's Bay during 2013-14 and 2014-15, followed by two inoculations of either 250 Eutypa lata ascospores or 500 Neofusicoccum luteum conidia, applied in $20-\mu l$ droplets to each wound ${ }^{\mathrm{a}}$

\begin{tabular}{|c|c|c|c|c|c|c|c|c|c|}
\hline \multirow[b]{3}{*}{ Sprayer } & \multirow[b]{3}{*}{ WSV $^{\mathbf{b}}$ (liters/ha) } & \multirow{2}{*}{\multicolumn{2}{|c|}{$\begin{array}{c}\text { Mean spray coverage } \\
(\%)\end{array}$}} & \multirow{2}{*}{\multicolumn{2}{|c|}{$\frac{\text { E. lata }}{\text { Combined years }}$}} & \multicolumn{4}{|c|}{ N. luteum } \\
\hline & & & & & & \multicolumn{2}{|c|}{ 2013-14 } & \multicolumn{2}{|c|}{ 2014-15 } \\
\hline & & 2013-14 & 2014-15 & $\mathbf{M P R}^{\mathrm{d}}$ & MPDC $^{\mathbf{e}}$ & MPR & MPDC & MPR & MPDC \\
\hline Inoculated control & $\ldots$ & $\ldots$ & $\ldots$ & 38 & $\ldots$ & 90 & $\ldots$ & 48 & $\ldots$ \\
\hline Paintbrush & $\ldots$ & 100 & 100 & $14^{*}$ & 63 & 90 & 0 & $16^{*}$ & 67 \\
\hline \multirow[t]{2}{*}{ Air-shear } & 300 & 81 & 65 & $9^{*}$ & 75 & 80 & 11 & $8^{*}$ & 83 \\
\hline & 600 & 84 & 88 & $11^{*}$ & 71 & 83 & 8 & $6^{*}$ & 87 \\
\hline \multirow[t]{2}{*}{ Weed } & 100 & 81 & 46 & $7 *$ & 81 & 77 & 14 & $11^{*}$ & 77 \\
\hline & 200 & 86 & 50 & $12^{*}$ & 68 & 80 & 11 & $10^{*}$ & 80 \\
\hline Recycle & 900 & 98 & 90 & $12^{*}$ & 68 & 70 & 23 & $10 *$ & 78 \\
\hline
\end{tabular}

a Values with an asterisk are significantly different from the inoculated control according to Fisher's LSD test.

${ }^{\mathrm{b}} \mathrm{WSV}=$ water spray volume.

${ }^{\mathrm{c}}$ Mean spray coverage based on water-sensitive paper analysis.

${ }^{\mathrm{d}}$ Efficacy was based on the mean percent recovery (MPR) of E. lata or $N$. luteum from the treated canes by isolation on potato dextrose agar.

${ }^{\mathrm{e}}$ Mean percent disease control (MPDC) of treatments was calculated as the reduction in MPR as a proportion of the inoculated control. 
treatments between trials, data were not pooled. In 2013-14, there was no significant treatment effect $(P=0.342)$ with MPR of $N$. luteum not reduced with any of the application methods, including with a paintbrush. In 2014-15, there was a significant treatment effect $(P=0.001)$ with MPR of $N$. luteum reduced to 6 to $16 \%$ for all applications (MPDC of 67 to $87 \%$ ).

In Hawke's Bay, the mean spray coverage in 2013-14, according to analysis of WSPs, was estimated to range from $81 \%$ for the lower water volumes of the air-shear (WSV of 300 liters/ha) and weed sprayer (100 liters/ha) up to $98 \%$ for the recycle sprayer (900 liters/ha; Table 4). Application with a paintbrush was until runoff and so represented $100 \%$ coverage. There were slight increases with both the air-shear and weed sprayers when the WSV was increased to 600 and 200 liters/ha, respectively. In 2014-15, mean spray coverage was estimated to range from $46 \%$ for the lowest water volume with the weed sprayer (100 liters/ha) up to $90 \%$ for the recycle sprayer (900 liters/ha). Overall, spray coverage was lower in 2014 than in 2013, with the exception of the air-shear sprayer with WSV of 600 liters/ha.

In Marlborough, E. lata spore germination on PDA for both inoculation times was 92 to $96 \%$ in 2013-14 and 91 to $95 \%$ in 2014-15, and E. lata was recovered from 55 and $65 \%$ of IC wounds, respectively. E. lata was recovered from 6\% of NIC wounds in 2013-14, but none was recovered in 2014-15. Relative recovery from treatments was similar between trials, so data were pooled. There was a significant treatment effect $(P<0.001)$ with MPR of $E$. lata reduced to 11 to $26 \%$ for all carbendazim applications compared with MPR of $60 \%$ in the IC wounds (MPDC of 56 to $81 \%$ ).

$N$. luteum spore germination on PDA for both inoculation times was 96 to $99 \%$ in 2013-14 and 90 to $97 \%$ in 2014-15. MPR of $N$. luteum from IC wounds was 72 and 52\% in 2013-14 and 2014-15 (Table 5) and was 28 and $15 \%$ from the NIC wounds, respectively. Owing to the large relative differences in recovery from treatments between trials, data were not pooled. In 2013-14, there was no significant treatment effect $(P=0.07)$ with MPR of $N$. luteum not reduced with any of the application methods, including with a paintbrush. In 2014-15, there was a significant treatment effect $(P<0.001)$ with MPR of $N$. luteum reduced to 5 to $25 \%$ for all applications (MPDC of 52 to $91 \%$ ).

In Marlborough, the mean spray coverage in 2013-14 ranged from $74 \%$ for the lower WSV of the air-shear sprayer (300 liters/ha) up to $96 \%$ for the tangential sprayer (600 liters/ha; Table 5). Application with a paintbrush was until runoff, and so represented $100 \%$ coverage. There were slight increases with both the air-shear and tangential sprayers when the WSV was increased to 600 liters/ha. In 2014-15, mean spray coverage ranged from $64 \%$ for the lowest WSV with the air-shear sprayer (300 liters/ha) up to $97 \%$ for the tangential sprayer (600 liters/ha). Overall, spray coverage was lower in 2014 than in
2013, with the exception of the tangential and air-shear sprayers with WSV of 600 liters/ha.

\section{Discussion}

For this study, E. lata was chosen to represent Eutypa dieback, because it is the most common and virulent species of the Diatrypaceae worldwide (Trouillas et al. 2010), and it is the only species of this family recorded on grapevines in New Zealand. N. luteum was chosen to represent Botryosphaeria dieback instead of N. parvum, the most common species reported in New Zealand (Amponsah et al. 2011; Baskarathevan et al. 2012). In preliminary experiments, high rates of preexisting or natural $N$. parvum infection recovered from uninoculated canes led to high background recovery, making statistical analysis for efficacy of fungicides difficult (data not shown). For the five fungicides evaluated here, previous studies have shown similar efficacy among multiple Botryosphaeriaceae species (Amponsah et al. 2012; Úrbez Torres 2011). Therefore, it can be assumed that efficacy results here are reflective of the wider range of species that cause Botryosphaeria dieback.

To ensure significant establishment of infection in controls, wounds were inoculated with 500 ascospores of E. lata or 1,000 conidia of $N$. luteum. Furthermore, in the field trials, two separate inoculations of 250 ascospores (E. lata) or 500 conidia ( $N$. luteum) were made several days apart to maximize likelihood of infection. These spore doses represented 50 to 100 times the number estimated to infect a pruning wound naturally with E. lata (Carter and Moller 1971). The high MPR from inoculated controls can be attributed to the relatively large spore doses applied to wounds (Ayres et al. 2017; Elena et al. 2015), especially compared with the recovery from noninoculated controls of 3 to $6 \%$ (E. lata) and 12 to $17 \%$ (N. luteum) in these vineyard trials, which reflected natural disease pressure. In the current study, when disease pressure was moderate (i.e., 40 to $60 \%$ recovery from inoculated controls), fungicide efficacy was far greater than when the disease pressure was high $(>60 \%)$. Similar results have been reported from Australia (Ayres et al. 2017; Sosnowski et al. 2013). In future, pruning wound treatments should be evaluated at lower disease pressures, by reducing the inoculum dose. Therefore, these results indicate that all the fungicides, at the lowest application rates evaluated, will potentially provide control of both Eutypa and Botryosphaeria dieback under natural vineyard disease conditions. At the time of publication, tebuconazole (Gelseal Ultra) has been registered in New Zealand for control of Eutypa dieback and fluazinam (Gem) registered for control both Eutypa and Botryosphaeria dieback, and an application is in progress for a third, flusilazole (Megastar), to also be registered for both diseases.

For the evaluation of spray application in the vineyard, carbendazim was chosen based on its efficacy against E. lata and N. luteum in past studies (Amponsah et al. 2012; Bourbos and Barbopoulou 2005;

Table 5. Efficacy of carbendazim when applied to fresh grapevine pruning wounds at $0.129 \mathrm{~g}$ of a.i./liter using tractor-driven sprayers with variable water output rates, in Marlborough during 2013-14 and 2014-15, followed by two inoculations of either 250 Eutypa lata ascospores or 500 Neofusicoccum luteum, applied in $20-\mu l$ droplets to each wound ${ }^{\mathrm{a}}$

\begin{tabular}{|c|c|c|c|c|c|c|c|c|c|}
\hline \multirow[b]{3}{*}{ Sprayer } & \multirow[b]{3}{*}{ WSVb (liters/ha) } & \multirow{2}{*}{\multicolumn{2}{|c|}{$\begin{array}{c}\text { Mean spray coverage } \\
(\%)\end{array}$}} & \multirow{2}{*}{\multicolumn{2}{|c|}{$\frac{E . \text { lata }}{\text { Combined years }}$}} & \multicolumn{4}{|c|}{ N. luteum } \\
\hline & & & & & & \multicolumn{2}{|c|}{ 2013-14 } & \multicolumn{2}{|c|}{ 2014-15 } \\
\hline & & 2013-14 & 2014-15 & MPR $^{d}$ & MPDCe & MPR & MPDC & MPR & MPDC \\
\hline Inoculated control & $\ldots$ & $\ldots$ & $\ldots$ & 59 & $\ldots$ & 72 & $\ldots$ & 52 & $\ldots$ \\
\hline Paintbrush & $\ldots$ & 100 & 100 & $16^{*}$ & 73 & 39 & 46 & $5 *$ & 91 \\
\hline \multirow[t]{2}{*}{ Tangential } & 300 & 92 & 85 & $26^{*}$ & 56 & 66 & 8 & $18^{*}$ & 66 \\
\hline & 600 & 96 & 97 & $18^{*}$ & 69 & 63 & 12 & $9 *$ & 83 \\
\hline \multirow[t]{2}{*}{ Air-shear } & 300 & 74 & 64 & $22 *$ & 62 & 60 & 17 & $20 *$ & 62 \\
\hline & 600 & 76 & 84 & $16^{*}$ & 73 & 58 & 19 & $25 *$ & 52 \\
\hline Recycle & 850 & 93 & 79 & $11 *$ & 81 & 51 & 29 & $11 *$ & 79 \\
\hline
\end{tabular}

a Values with an asterisk are significantly different from the inoculated control according to Fisher's LSD test.

${ }^{\mathrm{b}} \mathrm{WSV}=$ water spray volume.

${ }^{\mathrm{c}}$ Mean spray coverage based on water-sensitive paper analysis.

${ }^{\mathrm{d}}$ Efficacy was based on the mean percent recovery (MPR) of E. lata or $N$. luteum from the treated canes by isolation on potato dextrose agar.

e Mean percent disease control (MPDC) of treatments was calculated as the reduction in MPR as a proportion of the inoculated control. 
Gramaje et al. 2012; Sosnowski et al. 2008, 2013) to demonstrate the ability of commonly used tractor-driven sprayers to deliver fungicide to wounds and provide equal protection to that of application by hand with a paintbrush. Therefore, based on the efficacy of all fungicides evaluated in the first part of this study and the control of E. lata achieved when applying tebuconazole with tractor-driven sprayers (Ayres et al. 2017), it can be assumed that these results will extend to each of the fungicides evaluated in this study.

In this study, all sprayers controlled both pathogens, except in the case of the 2013-14 trials, in which $N$. luteum disease pressure was extremely high, with MPR of 90 and $72 \%$ in ICs for Hawke's Bay and Marlborough, respectively. These results confirm those of Sosnowski et al. (2013) and Ayres et al. (2017), in which the application of carbendazim and tebuconazole, respectively, using a range of sprayers, resulted in control of E. lata on pruning wounds of spurpruned 'Riesling', Cabernet Sauvignon, Shiraz, and 'Tempranillo' grapevines. Ayres et al. (2017) reported significant control when WSP coverage exceeded $23 \%$, with increased control related to greater wound coverage. In the current study, wound coverage was also assessed with WSP and ranged from 46 to $100 \%$ for all sprayers and water spray volumes. Although spray coverage on WSP provides a relative indication of wound coverage, the actual coverage on wounds may be different, and so future research is required to validate WSP coverage with wound coverage.

As with the fungicide evaluations, results from 2013-14 were confounded by the greater MPR of $N$. luteum from inoculated controls in both regions ( 72 to $90 \%$ ). This again reflected high disease pressure compared with that normally expected in natural conditions according to MPR from noninoculated controls in these trials (15 to 28\%). There was an extremely high MPR $(72 \%)$ of $N$. luteum from noninoculated controls in the 2013-14 vineyard trial in Hawke's Bay. This result was difficult to explain, and such high natural rates of infection have not been reported in winter for this species elsewhere in the literature.

In conclusion, these results confirm those of Sosnowski et al. (2013) and Ayres et al. (2017) for E. lata and extend them to the efficacy of spray application for protecting pruning wounds from both E. lata and N. luteum on cordon-pruned Cabernet Sauvignon and cane-pruned Sauvignon blanc vines.

The cost of applying fungicides with tractor-driven sprayers was estimated at US\$87/ha (Sosnowski and McCarthy 2017). The cost of hand painting wounds in a cane-pruned vineyard was estimated to be double (US\$166/ha), and in a cordon spur-pruned vineyard the cost quadrupled (US\$333/ha). This, together with results from the current study, will encourage growers to apply fungicide wound protection from as early as the first pruning season, as recommended from economic studies (Kaplan et al. 2014; Sosnowski and McCarthy 2017).

During this study it was highlighted that, particularly for canepruned vines, there were large gaps in between vines without pruning wounds to target. The use of a recycle sprayer will alleviate the high rates of off-target deposits that occur when spraying dormant vines, with no expected decline in fungicide efficacy from recirculated spray mix, as was reported for Botrytis bunch rot (Raw et al. 2012). However, owing to the inhibitive cost of purchasing a new recycle sprayer for some growers, there is also a need for future development of precision spraying techniques for conventional nonrecycling sprayers already in use on vineyards. Retrofitted ultrasonic sensor systems could potentially limit the release of spray to the head of cane-pruned vine trunks when passing along the row (Palleja Cabre et al. 2017).

To the authors' knowledge, the first registration of a fungicide, fluazinam (Gem), for simultaneous control of both Eutypa and Botryosphaeria dieback has resulted from this study, and this is the first report of Botryosphaeria dieback control through fungicide application to wounds with tractor-driven sprayers. Current research is focusing on the timing of application to determine the preventative and curative properties of fungicides, the duration of susceptibility of wounds at different times of the pruning season and in climatically diverse environments, and the timing of spore dispersal. This will further improve recommendations for efficient and effective management of Eutypa and Botryosphaeria dieback.

\section{Acknowledgments}

The authors acknowledge technical support from Matthew Ayres (South Australian Research and Development Institute) and Bhanupratap Vanga (Plant \& Food Research) and statistical advice from Helena Oakey and Wendy $\mathrm{Li}$ (Biometry Hub, School of Agriculture, Food and Wine, The University of Adelaide).

\section{Literature Cited}

Amponsah, N. T., Jones, E., Ridgway, H. J., and Jaspers, M. V. 2012. Evaluation of fungicides for the management of Botryosphaeria dieback diseases of grapevines. Pest Manag. Sci. 68:676-683.

Amponsah, N. T., Jones, E. E., Ridgway, H. J., and Jaspers, M. V. 2011. Identification, potential inoculum sources and pathogenicity of botryosphaeriaceous species associated with grapevine dieback disease in New Zealand. Eur. J. Plant Pathol. 131:467-482.

Ayres, M. R., Wicks, T. J., Scott, E. S., and Sosnowski, M. R. 2017. Developing pruning wound protection strategies for managing Eutypa dieback. Aust. J. Grape Wine Res. 23:103-111.

Baskarathevan, J., Jaspers, M. V., Jones, E. E., and Ridgeway, H. J. 2012. Incidence and distribution of botryosphaeriaceous species in New Zealand vineyards. Eur. J. Plant Pathol. 132:549-560

Bester, W., Crous, P. W., and Fourie, P. H. 2007. Evaluation of fungicides as potential grapevine pruning wound protectants against Botryosphaeria species. Australas. Plant Pathol. 36:73-77.

Bourbos, V. A., and Barbopoulou, E. A. 2005. Study of the possibility to control Eutypa lata (Pers. Fr.) Tul. in grapevine. Phytopathol. Mediterr. 44:116.

Carter, M. V. 1991. The Status of Eutypa lata as a Pathogen. Phytopathological Paper No. 32. International Mycological Institute, Surrey, U.K.

Carter, M. V., and Moller, W. J. 1971. The quantity of inoculum required to infect apricot and other Prunus species with Eutypa armeniacae. Aust. J. Exp. Agric. Anim. Husb. 11:684-686.

Díaz, G. A., and Latorre, B. A. 2013. Efficacy of paste and liquid fungicide formulations to protect pruning wounds against pathogens associated with grapevine trunk diseases in Chile. Crop Prot. 46:106-112.

Elena, G., Sosnowski, M. R., Ayres, M. R., Lecomte, P., Benetreau, C., GarciaFigueres, F., and Luque, J. 2015. Effect of the inoculum dose of three grapevine trunk pathogens on the infection of artificially inoculated pruning wounds. Phytopathol. Mediterr. 54:345-354.

Gramaje, D., Ayres, M. R., Trouillas, F. P., and Sosnowski, M. R. 2012. Efficacy of fungicides on mycelial growth of diatrypaceous fungi associated with grapevine trunk disease. Australas. Plant Pathol. 41:295-300.

Gramaje, D., Úrbez-Torres, J. R., and Sosnowski, M. R. 2018. Managing grapevine trunk diseases with respect to etiology and epidemiology: Current strategies and future prospects. Plant Dis. 102:12-39.

Halleen, F., Fourie, P. H., and Lombard, P. J. 2010. Protection of grapevine pruning wounds against Eutypa lata by biological and chemical methods. S. Afr. J. Enol. Vitic. 31:125-132.

Herche, R., and Gubler, W. D. 2010. Control strategies for trunk diseases of grapevine. Phytopathol. Mediterr. 49:125.

Kaplan, J. D., Travadon, R., Cooper, M., Hillis, V., Lubell, M., and Baumgartner, K. 2014. An economic case for early adoption of preventative practices for management of grapevine trunk diseases. Phytopathol. Mediterr. 53:583.

Lecomte, P., Laveau, E., Laterriere, S. G., Dewasme, C., and Clerjeau, M. 2003 Optimisation of pruning wound protection for the control of Eutypa dieback of grapevine in France. IOBC/WPRS Bull. 26:95-96.

Mangado, J., Arazuri, S., Arnal, P., Jarén, C., and López, A. 2013. Measuring the accuracy of a pesticide treatment by an image analyzer. Procedia Technol. 8 : 498-502.

Moller, W. J., and Kasimatis, A. N. 1981. Further evidence that Eutypa armeniacae - not Phomopsis viticola - incites dead arm symptoms on grape. Plant Dis. 65:429-431.

Molyneux, R. J., Mahoney, N., Bayman, P., Wong, R. Y., Meyer, K., and Irelan, N. 2002. Eutypa dieback in grapevines: Differential production of acetylenic phenol metabolites by strains of Eutypa lata. J. Agric. Food Chem. 50: 1393-1399.

Munkvold, G. P., and Marois, J. J. 1993. The effects of fungicides on Eutypa lata germination, growth, and infection of grapevines. Plant Dis. 77:50-55.

Palleja Cabre, T., Llorens, J., and Landers, A. J. 2017. Measuring crop canopy-The development of a dynamic system for precision fruit crop spraying. Adv. Anim. Biosci. 8:250-254

Pitt, W. M., Sosnowski, M. R., Huang, R., Qiu, Y., Steel, C. C., and Savocchia, S. 2012. Evaluation of fungicides for the management of Botryosphaeria canker of grapevines. Plant Dis. 96:1303-1308.

Ramsdell, D. C. 1995. Winter air-blast sprayer applications of benomyl for reduction of Eutypa dieback disease incidence in a Concord grape vineyard in Michigan. Plant Dis. 79:399-402.

Raw, V., Mundy, D. C., McLachlan, A. R. G., Clifford, C., and Walter, M. 2012 Botrytis cinerea control on Sauvignon blanc using a recycling sprayer. N. Z. Plant Prot. 65:249-255. 
Savocchia, S., Laurent, E. N., Stodart, B. J., and Steel, C. C. 2005. Botryosphaeria canker and sensitivity to fungicides in vitro. In: 43rd Ann. Cong. South. Afr. Soc. Plant Pathol. Hartenbos, South Africa.

Siebert, J. B. 2001. Eutypa: The economic toll on vineyards. Wines Vines 82:50-56.

Sipiora, M. J., and Cuellar, S. 2014. Economic impact of Eutypa dieback. Wine Bus. Mon. (October) 21:46-49.

Sosnowski, M., and McCarthy, G. 2017. Economic impact of grapevine trunk disease management in Sauvignon blanc vineyards of New Zealand. Wine Vitic. J. 32:42-48.

Sosnowski, M. R., Creaser, M. L., Wicks, T. J., Lardner, R., and Scott, E. S. 2008. Protection of grapevine pruning wounds from infection by Eutypa lata. Aust. J. Grape Wine Res. 14:134-142.

Sosnowski, M. R., Loschiavo, A. P., Wicks, T. J., and Scott, E. S. 2013. Evaluating treatments and spray application for the protection of grapevine pruning wounds from infection by Eutypa lata. Plant Dis. 97:1599-1604.
Tey-Rulh, P., Philippe, I., Renaud, J. M., Tsoupras, G., De Angelis, P., Fallot, J., and Tabacchi, R. 1991. Eutypine, a phytotoxin produced by Eutypa lata the causal agent of dying-arm disease of grapevine. Phytochemistry 30 471-473.

Trouillas, F. P., Pitt, W. M., Sosnowski, M. R., Huang, R., Peduto, F., Loschiavo, A., Savocchia, S., Scott, E. S., and Gubler, W. D. 2011. Taxonomy and DNA phylogeny of Diatrypaceae associated with Vitis vinifera and other woody plants in Australia. Fungal Divers. 49:203-223.

Trouillas, F. P., Úrbez-Torres, J. R., and Gubler, W. D. 2010. Diversity of diatrypaceous fungi associated with grapevine canker diseases in California. Mycologia 102:319-336.

Úrbez Torres, J. R. 2011. The status of Botryosphaeriaceae species infecting grapevines. Phytopathol. Mediterr. 50:S5-S45.

Wicks, T., and Davies, K. 1999. The effect of Eutypa on grapevine yield. Aust. Grapegrow. Winemak. 426a:15-16. 